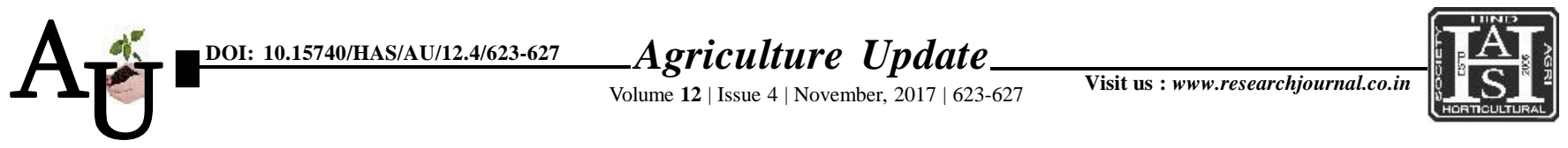

—e ISSN-0976-6847

\title{
Research article: Constraints in dairy entrepreneurship among youth in Telangana state
}

\section{KARTHIK, M.C.A. DEVI AND S. SUBASH}

Article Chronicle : Received :

17.08.2017;

Revised :

14.09.2017;

Accepted :

01.10 .2017

KeY Words :

Constraints, Dairy,

Entrepreneurship,

Youth

Author for correspondence :

\section{KARTHIK}

Southern Regional

Station of ICAR-

National Dairy Research

Institute, BENGALURU

(KARNATAKA) INDIA

See end of the article for

authors' affiliations
SUMMARY : The present study has been taken up with an objective to study constraints experienced by youth in dairy entrepreneurship. A sample of 220 respondents from 11 mandals were selected through proportionate random sampling from Telangana State. Inadequate availability of quality inputs at reasonable price was the major constraints among production constraints, low level of awareness about milk processing technologies was the major constraint among processing constraints, nonremunerative price of milk was the major marketing constraint and delayed payment of milk bill to farmers was major constraint among miscellaneous constraints.

How to cite this article : Karthik, D., Devi, M.C.A. and Subash, S. (2017). Constraints in dairy entrepreneurship among youth in Telangana state. Agric. Update, 12(4): 623-627; DOI : 10.15740/HAS/AU/12.4/623-627. 